\title{
Enhancement of Science Process Skills Through Quantum Learning Strategy in Students Public Elementary School of Tegal Alur 15 Pagi, Indonesia - A Case Study
}

\author{
${ }^{1}$ Septi Liana Sari , ${ }^{2}$ Mohamad Syarif Sumantri and ${ }^{3}$ Robinson Situmorang \\ ${ }^{1}$ Postgraduate Student ${ }^{2}$ Professor and ${ }^{3}$ Doctor \\ State University of Jakarta
}

Indonesia

\begin{abstract}
This study aims to find out the improvement of science process skills through quantum learning strategy in grade V SD Negeri Tegal Alur 15 Pagi Kalideres West Jakarta. The method in this research is classroon action research of Kemmis and McTaggart model which done for 2 cycle. Each cycle consists of planning, implementation, action, observation, and reflection. The results showed that the average percentage of science process skills score in the pre cycle stage was $39.88 \%$ and then increased to $64.38 \%$ at the end of cycle I, and increased again to $80.01 \%$ at the end of cycle II. The results of the calculation of teacher observation sheet in the first cycle that is $71.05 \%$ also increased in the second cycle that is $82.89 \%$. Result of student observation sheet in the first cycle average is $66,77 \%$ and increase in cycle II that becomes $80,58 \%$. The conclusion of this research is the increasing of science process skills of class V student SD Negeri Tegal Alur 15 Pagi through the use of quantum learning strategy in science lesson about the properties of light and its utilization.
\end{abstract}

Keywords: Science Process Skills, Quantum Learning Strategy, Action Research.

\section{INTRODUCTION}

Schools are a formal place for teaching and learning activities that specifically involve students and teachers in the interaction of the learning process. Through learning activities, students will be guided to master certain lessons in school. Basically learning activities at school will be effective if students learn in a positive circumstances and free from feeling depressed. Positive circumstances mean students are ready to learn physically in a healthy state and learn based on their own volition not because of forced or feel forced. Related to this, a teacher must be able to create a learning process that contains fun activities so that students feel happy and not bored to learn. In addition, the process of learning activities in schools must also be meaningful. Learning activities should be designed so that students are able to understand the meaning of the activities that they do. In order to make meaningful learning, especially the lesson of Natural Science, the learning activity must involve students directly with nature. The above description has not been fully implemented. According to Ahmad Susanto (2013), one of the problems facing the world of education today is the problem of weak implementation of learning process applied by teachers in schools. This also happens in the science lesson. The learning process that occurred during this less able to develop students' thinking ability. Implementation of the learning process that takes place in the classroom is only directed at the ability of students to memorize information provided by the teacher or obtained from the book. The student's brain is forced only to remember and hoard information without being required to understand the information obtained to relate it to the situation in everyday life.

This situation also happened at SD Negeri Tegal Alur 15 Pagi Kalideres West Jakarta. Learning activities are focused only on the delivery of material from textbooks without conducting learning activities that prioritize the development of students' science process skills. Based on the reality of observations conducted by researchers at SD Negeri Tegal Alur 15 Pagi towards science lesson that took place, it turns out that learning activities are only done in the classroom without any learning activities that make students interact directly with nature. The results of interview to three teachers who have taught in class V SD Negeri Tegal Alur 
15 Pagi, they simultaneously say almost never practice in learning activities. The reasons expressed were varied, one of them was because there was no time. Such circumstances certainly make learning activities become less meaningful and only theoretical. Students are less invited to critical thinking, students do not find knowledge through a number of activities that prioritize science process skills. Associated with all the above description then a teacher must be able to design learning activities that can make students hone their science process skills through a number of fun activities and able to generate student activeness while learning. Basically, the learning process can take place well and meaningful for the students if the factors that influence also support and adequate. One of the important factors that can influence the success of the learning process in the classroom is the strategy or method used by the teacher to deliver the subject matter, as well as the Natural Science. Currently there are various kinds of learning strategies that teachers can use to improve students science process skills as well as to build strong interactions with students so that students' learning spirit increases. One of them is by applying quantum learning strategy. Through the strategy of quantum learning students are invited to learn in a fun way through a number of activities that can support students' learning in an auditory, visual, and kinesthetic way. In addition, a number of learning activities that enable students' science process skills also make students learn not only to prioritize aspects of knowledge alone but also aspects of values and attitudes that are in line with the objectives of science learning. So in the end with the application of quantum learning strategy on science learning will have an impact on improving the science process skills of students grade V SD Negeri Tegal Alur 15 Pagi.

\section{METHODOLOGY}

According to Patricia et al (2006) classroom action research is a powerful tool for teachers to use in the classroom. John (2012) added that classroom action research can be a solution to solve the problems and obstacles that occur during the learning activities take place. In line with the expert's opinion, this research is also a classroom action research that used model Kemmis and Mc Taggart. This research was conducted as an effort to improve the students' science process skills in SD Negeri Tegal Alur 15 Pagi using quantum learning strategy. The classroom action research in this research consists of four steps of activity, namely: (1) planning stage which includes the preparation of lesson plan, teaching materials, learning media to be used, student worksheets, assessment sheets activities of teachers and students, and the scoring criteria assessment sheet, (2) the stage of action implementation which is the realization of the planning stage, (3) the observation stage undertaken during the implementation of the action to the students' ability to apply their science process skills as well as, and (4) the reflection stage undertaken to analyze the action outcomes of teacher and student activities during the learning activities using quantum learning. Result of the reflection then becomes the reference for improvement to determine the re-planning in the second cycle and so on so that its implementation is more effective. The expected success criteria in this research is the improvement of science process skills of students grade V at SD Negeri Tegal Alur 15 Pagi. Research is considered successful if the activities of teachers and students during learning activities using quantum learning strategies can improve students' science process skills in each cycle. According Mulyasa (2008) in terms of process, the formation of student competencies declared successful and qualified if all students or at least there are $75 \%$ of students actively involved in learning activities both physically, mentally, socially, and have a passion for learning high, and also self-confidence. Therefore, in line with these provisions, this research is also considered successful if there are $\geq 75 \%$ of students with the percentage of science skills process tests on the material properties of light and its utilization has reached the Minimum Criteria of Completeness. That is, there are at least 21 students out of a total of 28 students who get a science process skills score $\geq$ 71. Data source in this research is qualitative data in the form of student and teacher observation result and quantitative data that is test score of students' science process skills. Technique of collecting data in this research is test and non test. Test techniques are used to capture data about students' science process skills. This test is used to measure the level of skill improvement of the student process skills at the end of each cycle. Non-test techniques in this study are used to capture data during the learning process takes place when action is given. The data of the action monitoring used comes from learning observation, field notes, and documentation during the learning activity.

\section{RESULTS AND DISCUSSION}

From the results of observations that researcher do before the action is given, researcher see that teacher dominate the course of learning. Chrisley revealed that quantum learning is a learning process that prioritizes practice, activities, illustrations that make learners easy to understand lessons learned. Students are less invited to be active by their teacher in learning activities. The pre test scores that researcher give to students about the properties of light and its use also indicate that students' science process skills score has not been in accordance with the minimum mastery standard. The following is presented in table form 
Table 1. Percentage of Pre-Action Science Process Skills

\begin{tabular}{|c|l|c|}
\hline No & Indicator of Science Process Skills & Pre Action \\
\hline 1 & Conduct an experiment & $38,89 \%$ \\
\hline 2 & Predicting & $22,70 \%$ \\
\hline 3 & Observing & $40,17 \%$ \\
\hline 4 & Classifying & $46,13 \%$ \\
\hline 5 & Inferring & $36,60 \%$ \\
\hline 6 & Communicating & $44,04 \%$ \\
\hline \multicolumn{2}{|c|}{ Mean } & $38,09 \%$ \\
\hline
\end{tabular}

From the data above can be seen that mean of students' science process skills score is $38.09 \%$. This means that students' science process skills has not reached the minimum mastery criteria. Based on the observation of the researcher and the score of pre action test, the researcher started the action on cycle I. The following is the result of the student science process skills test in cycle I

Table 2. Percentage of Cycle Science Process Skills I

\begin{tabular}{|c|c|c|}
\hline No & Indicator of Science Process Skills & Cycle I \\
\hline 1 & Conduct an experiment & $59,22 \%$ \\
\hline 2 & Predicting & $64,28 \%$ \\
\hline 3 & Observing & $73,80 \%$ \\
\hline 4 & Classifying & $66,07 \%$ \\
\hline 5 & Inferring & $59,52 \%$ \\
\hline 6 & Communicating & $63,39 \%$ \\
\hline \multicolumn{2}{|r|}{ Mean } & $64,38 \%$ \\
\hline
\end{tabular}

Based on the data obtained, the results of students' science process skills in the first cycle is still low. The smallest science process skills is conduct an experiment that is equal to $59,22 \%$. If sorted from the indicator with the smallest percentage to the largest then after the indicator conduct an experiment with the percentage of 59.22\% is the indicator inferring with the percentage of 59.52\%, communicatingg with a percentage of $63.39 \%$, predicting with a percentage of $64.28 \%$, classifying with percentage of $66.07 \%$, and the last is the observing indicator with a percentage of $73.80 \%$. If these six percentages are summed it will result in an average percentage of $64.38 \%$.

In addition, the reflection is also done based on the analysis of observations in cycle I. Based on the observation results there are still activities that have not been implemented well by teachers and students. The following table presents the percentage of successful actions of teachers and students in science learning using quantum learning strategy.

Table 3. Percentage of Teacher Action and Student in Science Lesson Using Quantum Learning Strategy Cycle I

\begin{tabular}{|c|c|c|}
\hline Observation & Meeting & $\begin{array}{c}\text { Percentage of } \\
\text { Success }\end{array}$ \\
\hline \multirow{4}{*}{ Teacher } & 1 & $64,47 \%$ \\
\cline { 2 - 3 } & 2 & $67,10 \%$ \\
\cline { 2 - 3 } & 3 & $75 \%$ \\
\cline { 2 - 3 } & 4 & $77,63 \%$ \\
\hline \multirow{4}{*}{ Student } & 1 & $60,52 \%$ \\
\cline { 2 - 3 } & 2 & $63,15 \%$ \\
\cline { 2 - 3 } & 3 & $68,42 \%$ \\
\cline { 2 - 3 } & 4 & $75 \%$ \\
\hline
\end{tabular}


Table 4. Achievement Category of Teachers and Students Activity

\begin{tabular}{|c|c|c|c|}
\hline Percentage & Score & Category & Success Rate Score \\
\hline $85-100 \%$ & 4 & Very Good & Success \\
\hline $65-84 \%$ & 3 & Good & Success \\
\hline $45-64 \%$ & 2 & Good Enough & Not success \\
\hline $25-44 \%$ & 1 & Less Good & Not success \\
\hline $0-24 \%$ & 0 & Not Good & Not success \\
\hline
\end{tabular}

Based on table above, it can be described that there is still achievement of teacher and student activity in cycle I that enter the category "Good Enough" so that can be stated "Not Success". This condition is stated on the observation result of teacher activity at first meeting with percentage $64,47 \%$ and observation result of student activity at first meeting with percentage $60,52 \%$ and second meeting with percentage $63,15 \%$. From the description above, the researcher and collaborators also reflect the factors that allow the lack of maximum results in the first cycle, such as: 1) the expression of cheerfulness and enthusiasm of teachers less radiated when opening lessons, 2) The teacher's voice volume is still smal for the capacity of primary school children. This causes students who sit in the back row is less able to listen to the workbook workmanship instructions that cause a bit of a commotion 3 ) Strengthening the verbal praise of student efforts to answer the question correctly is also still given a little. Likewise with the business students who have not maximized. The shortcomings that have been observed are 1) Students are not familiar with quantum learning strategy that prioritizes the skills of the science process so that the component of the science process skills raised by the students is not maximized; 2) students are not yet accustomed to learning in groups so that the class conditions become a bit crowded 2) student discussion is still dominated by students who have above average academic ability so there are some students who are less involved in the discussion.

Based on the results of this reflection, the researcher also plan to continue the action on cycle II. The actions of cycle II are the improving form of cycle I and the following is the result of science process skills test after the implementation of cycle II

Table 5. Percentage of Science Process Skills Cycle II

\begin{tabular}{|c|c|}
\hline Indicator of Science Process Skills & Percentage \\
\hline Conduct an experiment & $83,03 \%$ \\
\hline Predicting & $74,70 \%$ \\
\hline Observing & $86,60 \%$ \\
\hline Classifying & $83,33 \%$ \\
\hline Inferring & $77,08 \%$ \\
\hline Communicating & $75,29 \%$ \\
\hline Mean & $80,01 \%$ \\
\hline
\end{tabular}

In the second cycle there is an increase in the science process skills of SD Negeri Tegal Alur 15 Pagi students grade V. If sorted from highest to lowest the first one is observing 86,60\%, then classifying $83.33 \%$, then conduct an experiment $83.03 \%$, then inferring $77,08 \%$, communicating $75,29 \%$, then predicting $74.70 \%$. So the mean is $80.01 \%$. On the other hand, based on observations through the observation sheet of teacher and student activities, it also found an increase. The following table presents the percentage of teacher and student action in science learning using quantum learning strategy.

Table 6. Percentage of Teacher and Student Action Cycle II

\begin{tabular}{|c|c|c|}
\hline Observation & Meeting & Percentage \\
\hline Teacher & 1 & $78,94 \%$ \\
\hline
\end{tabular}




\begin{tabular}{|c|c|c|}
\hline Observation & Meeting & Percentage \\
\hline \multirow{7}{*}{ Student } & 2 & $82,89 \%$ \\
\cline { 2 - 3 } & 3 & $84,21 \%$ \\
\cline { 2 - 3 } & 4 & $85,52 \%$ \\
\hline \multirow{7}{*}{} & 1 & $76,31 \%$ \\
\cline { 2 - 3 } & 2 & $80,26 \%$ \\
\cline { 2 - 3 } & 3 & $81,57 \%$ \\
\hline & 4 & $84,21 \%$ \\
\hline
\end{tabular}

Percentage data in the table above then analyzed using success rate Table 4. Category Achievement of Teacher Activities and Students. The conclusion that can be taken is the result of teacher and student observation in cycle II first meeting until fourth is stated "Success". The percentage of teacher observation result in fourth act of cycle II is $85,52 \%$ with category "Very Good" which means "Success". This success also occurs in the observation result of student activity during science learning which is on the fourth action of cycle II with percentage of $84,21 \%$ "Good" category. The description of the above reflection makes the researcher conclude that science learning using quantum learning strategy has been going well. The actions undertaken have demonstrated improvements in students' science process skills as well as increased teacher and student activity in Pre-Action learning activities, Cycle I, and Cycle II. Referring to the predetermined indicator that the result obtained has exceeded the Minimum Criteria of Completeness, this study need not be continued to the next cycle.

\subsection{Discussion}

Based on the action research applied to students grade V at SD Negeri Tegal Alur 15 Pagi using quantum learning strategy, the result stated that the improvement of students' science process skills. This increase can occur naturally because of the process of reflection from one cycle to the next cycle so that all the deficiencies of the previous cycle can be improved and the advantages of the previous cycle can be maintained and improved again.Efforts to improve students' science process skills started from the implementation of cycle I consisting of four actions. Based on the results of the tests given to students at the end of the cycle then it appears the improvement of students' science process skills from pre-action to cycle II. More clearly can be seen in the table below:

Table 7. Science Process Skills Improvement

\begin{tabular}{|c|c|r|r|c|}
\hline No & Indicator of Science Process Skills & Pre Action & Cycle I & Cycle II \\
\hline 1 & Conduct an experiment & $38,89 \%$ & $59,22 \%$ & $83,03 \%$ \\
\hline 2 & Predicting & $22,70 \%$ & $64,28 \%$ & $74,70 \%$ \\
\hline 3 & Observing & $40,17 \%$ & $73,80 \%$ & $86,60 \%$ \\
\hline 4 & Classifying & $46,13 \%$ & $66,07 \%$ & $83,33 \%$ \\
\hline 5 & Inferring & $36,60 \%$ & $59,52 \%$ & $77,08 \%$ \\
\hline 6 & Communicating & $44,04 \%$ & $63,39 \%$ & $75,29 \%$ \\
\hline \multicolumn{2}{|c|}{ Mean } & $38,09 \%$ & $64,38 \%$ & $80,01 \%$ \\
\hline
\end{tabular}

The following is presented in the form of bar charts for easy visualization

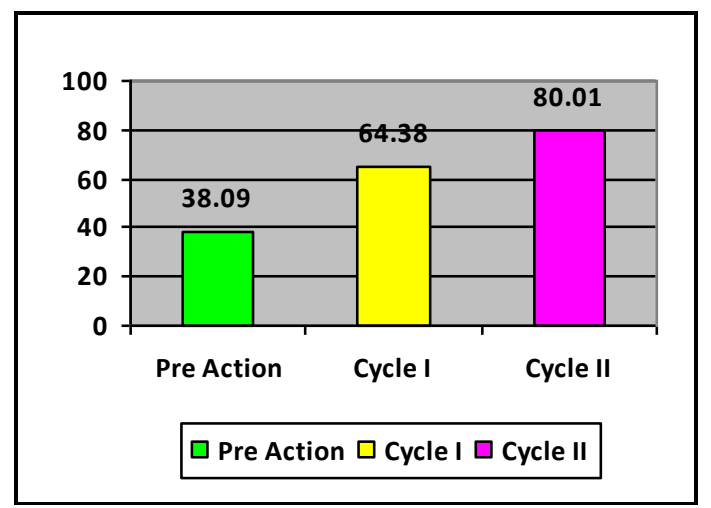




\section{Figure 1. Science Process Skills Score}

Through the table above it seems clear that the mean of science process skills in pre action is $38.09 \%$. This mean increased to $64.38 \%$ in cycle I and increased again to $80.01 \%$ in cycle II. This means that there is an increase of science process skills of students class V SD Negeri Tegal Alur 15 Pagi after the implementation of quantum learning strategy. In addition, the following table shows increased activity of teachers and students during the learning activity.

Table 8. Improved Observation Results Teacher Activity

\begin{tabular}{|c|c|c|}
\hline \multirow{2}{*}{ Meeting } & \multicolumn{2}{|c|}{ Percentage } \\
\cline { 2 - 3 } & Cycle I & Cycle II \\
\hline 1 & $64,47 \%$ & $78,94 \%$ \\
\hline 2 & $67,10 \%$ & $82,89 \%$ \\
\hline 3 & $75 \%$ & $84,21 \%$ \\
\hline 4 & $77,63 \%$ & $85,52 \%$ \\
\hline Mean & $71,05 \%$ & $82,89 \%$ \\
\hline
\end{tabular}

The result of teacher activity observation in cycle I has mean percentage of $71,05 \%$ which has increased to $82,89 \%$ in cycles II. The increase also occurred in the observation result of student activity. The increase is presented in the table below.

Table 9. Improved Observation Results of Student Activities

\begin{tabular}{|c|c|c|}
\hline \multirow{2}{*}{ Meeting } & \multicolumn{2}{|c|}{ Percentage } \\
\cline { 2 - 3 } & Cycle I & Cycle I \\
\hline 1 & $60,52 \%$ & $76,31 \%$ \\
\hline 2 & $63,15 \%$ & $80,26 \%$ \\
\hline 3 & $68,42 \%$ & $81,57 \%$ \\
\hline 4 & $75 \%$ & $84,21 \%$ \\
\hline Rata-rata & $66,77 \%$ & $80,58 \%$ \\
\hline
\end{tabular}

Based on the table then the observation of student activity was also increased to $80.58 \%$ in cycle II which was originally only $66.77 \%$ in cycle I. The following are presented in tabular form for easy visualization.

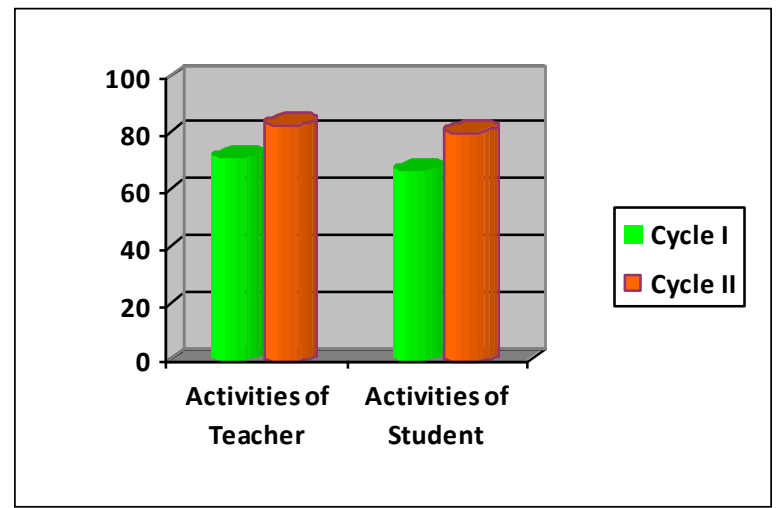

Figure 2. Observation Results of Teacher and Student Activity 
The result data of this research is proof that the students' science process skilsl can increase if students do some learning activities which give them an opportunity to actively participate in the learning process. This fact is in line with Saiful Sagala's opinion (2013) that teachers need to create varied learning activities so that students engage in various forms of learning experience so that with good process will get good results as well. Therefore, the learning activity in this research is done by using quantum learning strategy because through this strategy the students can be invited to be active in learning which is meaningful and fun.

The science lessons that have taken place in this study are commensurate with the statement of Nandang and Dede (2013) which states that quantum learning is a learning process that can sharpen understanding and memory and make learning as a fun and rewarding process. Through this research, students no longer learn to rely solely on teacher knowledge and package books but they proceed to actively participate through a number of activities according to quantum learning strategies

\section{CONCLUSION}

Based on the description contained in the previous about the results of the research analysis it can be concluded that,

1. Science lesson of light properties and its utilization using quantum learning strategy can improve science process skills students in SD Negeri Tegal Alur 15 Pagi grade V. Before action is given, the average percentage of students' science process skills is $38.09 \%$. After the action is given in cycle I, the average percentage of students' science process skills has increased to $64.38 \%$. The increasingly visible in cycle II is shown with the average science process skills to $80.01 \%$. The learning of science using quantum learning strategy in class V of SD Negeri Tegal Alur 15 Pagi able to increase the number of students who got test scores above the Minimum Criteria of Completeness (KKM). Before any action is given, no student gets scores of science process skill tests above the KKM. After the first cycle was implemented, the number of students who received the KKM datas test score increased to 7 students. The increase of students with the score of science process skills test above KKM also occurred in cycle II that is to be 24 people.

2. Observation and reflection stage conducted by teacher collaborators and researchers able to make the activities of teachers and students during the learning process continues to improve. This is evidenced from the average score of the results of teacher observation sheet in the first cycle that is $71.05 \%$ and increased in the second cycle that is $82.89 \%$. While the result of student observation sheet on the first cycle average score is $66.77 \%$ and increase in cycle II that is $80.58 \%$.

Based on the above description it can be concluded that the correctness of the research hypothesis has been proven. Improving students' science process skills, increasing teacher activity, and increasing student activity can be done by using quantum learning strategy in science learning of students grade V SD Negeri Tegal Alur 15 Pagi.

\section{IMPLICATIONS}

Based on the results of research that has been analyzed then the implications that can be found from this research are,

1. Teachers should make various efforts to create learning conditions that are able to make students actively involved in it so that students experience learning and learning becomes more meaningful.

2. Science learning should be delivered by continuing to advance the students' science process skills so that these skills can be continuously honed and will experience continuous improvement.

\section{SUGGESTION}

Based on the research that has been done, the researcher put forward some suggestions as follows

1. Students are expected to be actively involved in learning activities in order to find out for themselves what they learned as part of their efforts to improve their science process skills

2. Teachers should be able to create learning activities that enable students' science process skills so that learning takes place meaningfully. One of the strategies that can be applied by teachers to achieve the above goals is quantum learning strategy.

3. Through this research is expected to provide school support and guidance to teachers who want to apply quantum learning strategies on any subject.

\section{REFERENCES}


Septi Liana Sari et. al., Enhancement of Science Process Skills Through Quantum Learning

[1] John W. Creswell, "Educational Research; Planning, Conducting, and Evaluating Quantitative and Qualitative Research" Boston: Pearson Education, 2012, p. 577.

[2] Patricia J. Anderson, Katherine A. O’Connor, and H. Carol Greene, “Action Research: Questions Asked, Questions Answered," The Delta Kappa Gamma Buletin, 2006, p. 13.

[3] Mulyasa, E., "Menjadi Guru Profesional: Menciptakan Pembelajaran Kreatif dan Menyenangkan, Bandung: Remaja Rosdakarya”, 2008, p. 256.

[4] Sagala Syaiful, “Konsep dan Makna Pembelajara,” Bandung: Alfabeta, 2013, p. 74.

[5] Sumarna Dede, Nandang Kosasih, "Pembelajaran Quantum dan Optimalisasi Kecerdasan,” Bandung: Alfabeta, 2013 , p. 76.

[6] Susanto Ahmad, “Teori Belajar dan Pembelajaran di Sekolah Dasar,” Jakarta: Prenadamedia, 2013, p. 165. 